\title{
Strobilanthes heyneanus root extract as a potential source for antioxidant and antimicrobial activity
}

\author{
Vijayakumar Sundaram ${ }^{1}$ Selvaraju Sadhasivam ${ }^{1 *}$, Sivaraj Chandrasekaran², Raaman Nanjian ${ }^{3}$ and Arjun Pandian ${ }^{4}$
}

\begin{abstract}
Background: Strobilanthes heyneanus (Nilgirianthus heyneanus) belongs to the family Acanthaceae that contains many species with potential for diverse medicinal uses. It is also called 'Karun kurinji' and is commonly found in the South-West regions of India. The species are commonly used in rheumatic complaints, sprain of the ankle, and hernia. The objectives of the study were to evaluate the antioxidant activity, phytochemical analysis, and antibacterial activities of the root extract of $S$. heyneanus.

Results: The radical scavenging and reduction assays such as $\mathrm{DPPH}^{\bullet}$ radical and $\mathrm{OH}^{\bullet}$ radical scavenging assays, as well as phosphomolybdenum reduction and $\mathrm{Fe}^{3+}$ reducing power assays, were determined for the root extract. The highest DPPH ${ }^{\bullet}$ radical scavenging activity was $88.23 \pm 1.32$ at $120 \mu \mathrm{g} / \mathrm{mL}$ concentration, and the calculated $I_{50}$ was $38.52 \mu \mathrm{g} / \mathrm{mL}$ concentration. The highest $\mathrm{OH}^{\bullet}$ radical scavenging activity was $51.28 \pm 1.06$ at $120 \mu \mathrm{g} / \mathrm{mL}$ concentration, and the calculated $I C_{50}$ was $51.28 \mu \mathrm{g} / \mathrm{mL}$ concentration. The highest ABTS ${ }^{\bullet+}$ radical scavenging activity was $91.28 \pm 1.12$ at $30 \mu \mathrm{g} / \mathrm{mL}$ concentration, and the calculated $I_{50}$ was $33.92 \mu \mathrm{g} / \mathrm{mL}$ concentration. The highest phosphomolybdenum reduction was $87.43 \pm 0.90$ at $120 \mu \mathrm{g} / \mathrm{mL}$ concentration, and the calculated $\mathrm{RC}_{50}$ was $24.74 \mu \mathrm{g} / \mathrm{mL}$ concentration. The highest Fe ${ }^{3+}$ reduction was $89.38 \pm 0.98$ at $120 \mu \mathrm{g} / \mathrm{mL}$ concentration, and the calculated $\mathrm{RC}_{50}$ was $31.06 \mu \mathrm{g} / \mathrm{mL}$ concentration. The antibacterial activity of $S$. heyneanus showed the highest zone of inhibition of $24 \mathrm{~mm}$ for Salmonella typhi with $500 \mu \mathrm{g} / \mathrm{mL}$ concentration. The cytotoxicity limits of the root extracts were tested by MTT assay using human dermal fibroblast cell lines, reflecting $>90 \%$ cell viability at a concentration of $500 \mu \mathrm{g} / \mathrm{mL}$.

Conclusions: The current study showed that the root extract of $S$. heyneanus has better antioxidant properties and potential anti-bacterial compounds. The phytochemical analysis of the root extract showed the presence of alkaloids, steroids, terpenoids, phenols, flavonoids, tannins, saponins, glycosides, and carbohydrates, which are responsible for the antibacterial root extract of $S$. heyneanus synergistically.
\end{abstract}

Keywords: Strobilanthes heyneanus, Phytochemicals, DPPH radical, MIC, MTT assay, Antioxidant, Antibacterial

\section{Statement of novelty}

The roots of Strobilanthes heyneanus are extremely used in the Ayurvedic drug preparation, one of the most efficient plant species available in India, and its pharmacological activity is not much revealed so far. The results

\footnotetext{
* Correspondence: selvarajuvaishnav@gmail.com

'Department of Plant Biology and Plant Biotechnology, D.G Vaishnav

College, Arumbakkam, Chennai, Tamilnadu 600106, India

Full list of author information is available at the end of the article
}

of antimicrobial activity revealed that the species has potential antibiotics against infections caused by the pathogens. Thus, our interest is to explore the pharmacological potential of bioactive compounds from the plant, Strobilanthes heyneanus, as a natural killer against disease to save people. This information on the species is useful for the discovery of the new drug for the pharmacological industry. 


\section{Background}

The family Acanthaceae contains several species with a potential diversity of ethnobotanical uses. One of the important species in this family is Strobilanthes heyneanus (Nilgirianthus heyneanus) mostly found in the southwest regions of India, commonly called Karun kurinji [1]. Ayurveda drugs prepared from this species are useful. They are commonly used in rheumatic complaints, sprain of the angle, and hernia. S. heyneanus, also called Karun Kurinji, is an undershrub, nearly a meter high, with a grooved stem, often covered with hairs. The leaves are oppositely arranged, unequal, ovate, and hairy and have a serrated margin. The flowers are blue urnshape of $1-1.2 \mathrm{~cm}$ long, which occur in axillary spikes, and five sepals are combined at the base. The flower tube is swollen in the middle which is a white colour and has five rounded petals. In the flower, the stamens are 4 , filaments are hairy at the base, and the capsule is 6-8 mm long, oblong, and 4-seeded. Karun kurinji is mostly found in the South-West of India and thought to be a type of Kurinji. Like Kurinji, it has a long flowering cycle and normally flowering from September to December [2]. S. heyneanus roots and leaves are used to treat leprosy, to control blood sugar, urinal problems, jaundice, inflammation, and excess menses [3]. The members of the genus Strobilanthes are used as an anti-diabetic, diuretic, laxative, and potent antimicrobial agents [4] (Fig. 1).

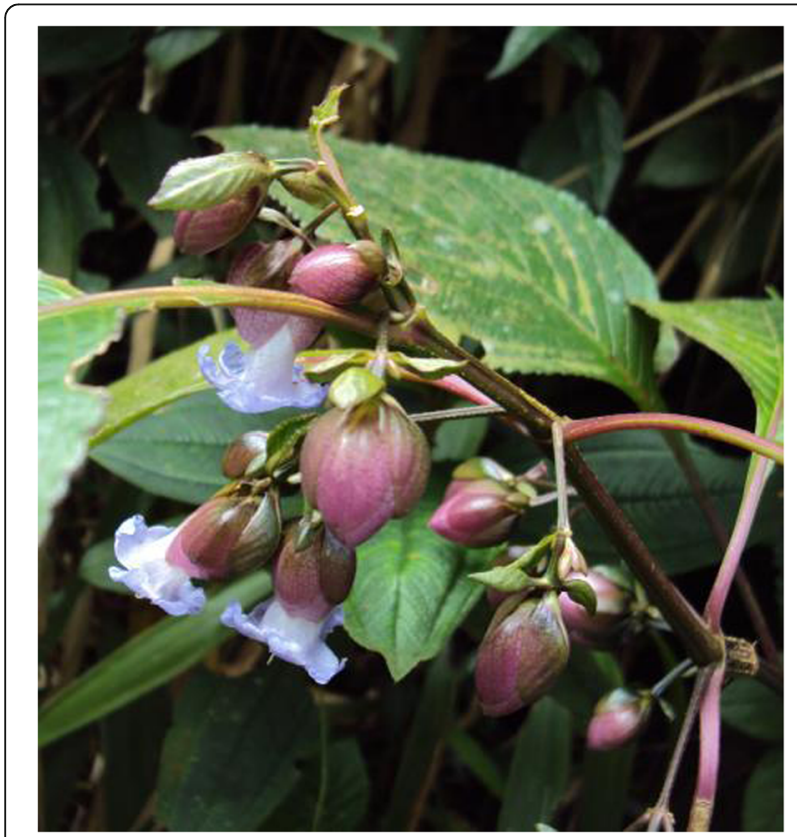

Fig. 1 Habitat of Strobilanthes heyneanus Nees. Taxonomic classification: kingdom, plant kingdom; division, angiosperms; class, Dicotyledoneae; subclass, Gamopetalae; family, Acanthaceae; genus, Strobilanthes; species, heyneanus

\section{Methods}

Plant collection and preparation of the extract

S. heyneanus plants were collected from Palchuram, Kottiyoor Road, Wayanad, Kerala, India. The specimen was deposited at the Centre for Repository of Medicinal Resources (C-RMR), Bangalore (Voucher No. FRLH 120018). The roots were separated, washed in distilled water, and dried for 2 days. The roots were powdered by using the mechanical blender and immersed in methanol for 3 days at room temperature. The clear supernatant above the plant powder residue was drained out through the filter paper and condensed by the rotary evaporator at $50{ }^{\circ} \mathrm{C}$, which yields blood-red colour viscous extract $[5,6]$.

\section{Phytochemical investigation}

The root extract of $S$. heyneanus was tested for phytochemical analysis for different categories of secondary metabolites of phytochemicals using specific chemical reagents $[7,8]$.

\section{Chemicals and reagents}

DPPH, ABTS, and Folin-Ciocalteu phenol reagents were procured from SRL India. Quercetin, sodium carbonate $\left(\mathrm{Na}_{2} \mathrm{CO}_{3}\right)$, absolute ethanol, Mueller-Hinton $(\mathrm{MH})$ agar, and gallic acid were obtained from Himedia, India. The other analytical grade common chemicals were purchased from the local vendors (Chennai, India).

\section{Total phenol estimation}

The total phenolic content was determined by the Folin-Ciocalteu reagent method with small modifications [9]. One hundred microlitres of the root extract $(1 \mathrm{mg} / \mathrm{mL})$ of $S$. heyneanus was mixed with $900 \mu \mathrm{L}$ of methanol and $1 \mathrm{~mL}$ of 1:10 diluted, Folin-Ciocalteu reagent. Next, $1 \mathrm{~mL}$ of $20 \%$ (w/v) $\mathrm{Na}_{2} \mathrm{CO}_{3}$ solution was added and shaken well. The reaction mixture was incubated in dark for $30 \mathrm{~min}$ at room temperature. At $765 \mathrm{~nm}$, the absorbance was measured and the total phenolic content was calculated as gallic acid equivalent $(\mu \mathrm{g} / \mathrm{mg}$ of extract).

\section{Total flavonoid estimation}

The total flavonoid content of the root extract of $S$. heyneanus was estimated by the aluminium chloride reagent method with small modifications [10]. Five hundred microlitres of extract $(1 \mathrm{mg} / \mathrm{mL})$ was mixed with $500 \mu \mathrm{L}$ of methanol, and to this, $0.5 \mathrm{~mL}$ of $5 \%(\mathrm{w} / \mathrm{v})$ sodium nitrite solution was added. Next, $500 \mu \mathrm{L}$ of aluminium chloride solution $(10 \%, \mathrm{w} / \mathrm{v})$ was added, followed by $50 \mu \mathrm{L}$ of $1 \mathrm{M} \mathrm{NaOH}$ solution and shaken well. The reaction mixture was incubated for $30 \mathrm{~min}$ at room temperature, and the absorbance was measured at 510 
$\mathrm{nm}$. The flavonoid content was calculated as quercetin equivalent $(\mu \mathrm{g} / \mathrm{mg}$ of extract).

\section{$\mathrm{DPPH}^{\bullet}$ radical scavenging activity}

The antioxidant activity of the root extract of $S$. heyneanus was measured by DPPH (1,1-diphenyl-2-picrylhydrazyl) radical scavenging assay method [11]. One millilitre of the root extract with different concentrations (20$120 \mu \mathrm{g} / \mathrm{mL}$ ) was mixed with $1 \mathrm{~mL}$ of $0.1 \mathrm{mM} \mathrm{DPPH}$ solution in methanol. One millilitre of DPPH solution mixed with $1 \mathrm{~mL}$ of methanol was used as the control. Then, the mixture was incubated in dark for $30 \mathrm{~min}$, and the absorbance was measured at $517 \mathrm{~nm}$. Ascorbic acid was used as the standard. The percentage of inhibition was calculated as:

$$
\begin{gathered}
\text { \%of } \mathrm{DPPH}^{\bullet} \text { radical inhibition } \\
=\frac{\text { Control-Sample }}{\text { Control }} \times 100
\end{gathered}
$$

\section{Hydroxyl radical scavenging assay}

The hydroxyl radical scavenging activity was analysed by the salicylic acid method with some minor modifications [12]. To $1 \mathrm{~mL}$ of various concentrations of the extract, $300 \mu \mathrm{L}$ of $\mathrm{FeSO}_{4}(8 \mathrm{mM})$ solution and $250 \mu \mathrm{L}$ of $\mathrm{H}_{2} \mathrm{O}_{2}$ $(20 \mathrm{mM})$ were added and shaken well. To start the reaction, $250 \mu \mathrm{L}$ of salicylic acid in methanol $(3 \mathrm{mM})$ was added, and then, the reaction mixture was incubated at $37^{\circ} \mathrm{C}$ for $30 \mathrm{~min}$. Then, $200 \mu \mathrm{L}$ of distilled water was added, and the mixture was centrifuged at $5000 \mathrm{rpm}$ for $5 \mathrm{~min}$. At $510 \mathrm{~nm}$, the absorbance of the supernatant was measured and the percentage of $\mathrm{OH}^{\bullet}$ radical scavenging activity was calculated as:

$$
\% \mathrm{of}^{\bullet} \text { radical inhibition }=\frac{\text { Control-Sample }}{\text { Control }} \times 100
$$

\section{$\mathrm{ABTS}^{\bullet+}$ radical cation scavenging activity}

The antioxidant ability of the root extract of $S$. heyneanus was evaluated by the ABTS ${ }^{\bullet+}$ radical cation scavenging assay method with slight modifications [13]. $\mathrm{ABTS}^{\bullet+}$ radical cation was obtained by $7 \mathrm{mM}$ of ABTS reacted with $2.45 \mathrm{mM}$ of potassium persulfate in 200 $\mathrm{mM}$ of PBS (pH 7.4) and incubated for $12-16 \mathrm{~h}$ in the dark before use. The ABTS ${ }^{\bullet+}$ radical cation solution was diluted with PBS and set an absorbance of $0.70 \pm 0.02$ at $734 \mathrm{~nm}$. Diluted $\mathrm{ABTS}^{\bullet+}$ radical cation solution was prepared freshly every day for this assay. Different concentrations $(5-30 \mu \mathrm{g} / \mathrm{mL})$ of the root extract was mixed with $500 \mu \mathrm{L}$ of diluted $\mathrm{ABTS}^{\bullet+}$ radical cation solution, and after $5 \mathrm{~min}$, the absorbance was measured at 734 $\mathrm{nm}$. Ascorbic acid was used as the standard reference. The $\mathrm{ABTS}^{\bullet+}$ radical cation scavenging activity was expressed as:

$$
\% \text { of } \mathrm{ABTS}^{\bullet+} \text { radical cation inhibition }=\frac{\text { Control-Sample }}{\text { Control }} \times 100
$$

\section{Phosphomolybdenum reduction assay}

The antioxidant capacity of the root extract of $S$. heyneanus was assessed by phosphomolybdenum reduction assay method [14]. One millilitre of various concentrations of the root extract $(20-120 \mu \mathrm{g} / \mathrm{mL})$ was mixed with $1 \mathrm{~mL}$ of reagent solution including ammonium molybdate $(4 \mathrm{mM})$, sodium phosphate $(28 \mathrm{mM})$, and sulphuric acid $(600 \mathrm{mM})$. The reaction mixture was incubated in a water bath at $95{ }^{\circ} \mathrm{C}$ for $90 \mathrm{~min}$, and the absorbance of the coloured complex was measured at $695 \mathrm{~nm}$. Ascorbic acid was used as the standard. The percentage of $\mathrm{Mo}^{6+}$ reduction was calculated as:

$$
\% \text { of } \mathrm{Mo}^{6+} \text { reduction }=\frac{\text { Sample-Control }}{\text { Sample }} \times 100
$$

\section{Ferric $\left(\mathrm{Fe}^{3+}\right)$ reducing power assay}

The assay for estimating the reducing power of the root extract of $S$. heyneanus was the potassium ferricyanide method with minor modifications [15]. One millilitre of the root extract of different concentrations $(20-120 \mu \mathrm{g} /$ $\mathrm{mL}$ ) was mixed with $1 \mathrm{~mL}$ of potassium ferricyanide $\left[\mathrm{K}_{3} \mathrm{Fe}(\mathrm{CN})_{6}\right](1 \% \mathrm{w} / \mathrm{v})$ solution and $1 \mathrm{~mL}$ of phosphate buffer (0.2 M, pH 6.6) solution. Then, the mixture was incubated at $50{ }^{\circ} \mathrm{C}$ in a water bath for $20 \mathrm{~min}$. Five hundred microlitres of trichloroacetic acid $(10 \% \mathrm{w} / \mathrm{v})$ was added to each mixture followed by $100 \mu \mathrm{L}$ of freshly prepared $\mathrm{FeCl}_{3}(0.1 \%, \mathrm{w} / \mathrm{v})$ solution which was added and shaken well. The absorbance was measured at $700 \mathrm{~nm}$. Ascorbic acid was used as the standard. The percentage of $\mathrm{Fe}^{3+}$ reduction was calculated as:

$$
\% \text { of } \mathrm{Fe}^{3+} \text { reduction }=\frac{\text { Sample-Control }}{\text { Sample }} \times 100
$$

\section{Antibacterial activity Organisms}

The Gram-positive organisms such as Bacillus subtilis (MTCC 441) and Staphylococcus aureus (MTCC 98), as well as the Gram-negative organisms such as Salmonella typhi (MTCC 734) and Klebsiella pneumonia (MTCC 109), were chosen for the antibacterial activity study.

\section{Standard}

Tetracycline was used as the standard compound for all the bacterial cultures.

\section{Mueller-Hinton agar}

$\mathrm{MH}$ agar was procured from HiMedia (HIMEDIAM173-500 G) to make up the medium for bacteria. The 
media was calculated $(38.0 \mathrm{~g} / \mathrm{L})$ depending upon the availability of strains and suspended in $150 \mathrm{~mL}$ of distilled water in a conical flask, stirred, boiled to dissolve, and then autoclaved at $15 \mathrm{lbs}$ and $121^{\circ} \mathrm{C}$ for $15 \mathrm{~min}$. The $\mathrm{pH}$ range was between 7.0 and 7.5 [16]. The hot medium was dispensed in sterile petri plates which were kept in sterile laminar airflow chamber and allowed to solidify for $15 \mathrm{~min}$.

\section{Disc diffusion method}

Antibacterial activity of root extract of $S$. heyneanus was carried out using the agar disc diffusion method. The MHA in the petri plates was inoculated by dispensing the inoculum using sterilised cotton swabs which are previously immersed in the inoculum containing test tube and spread evenly onto the solidified agar medium. Five sterile discs were taken, and the root extract was loaded onto the discs with different concentrations of $250 \mu \mathrm{g} / \mathrm{mL}, 375 \mu \mathrm{g} / \mathrm{mL}$, and $500 \mu \mathrm{g} / \mathrm{mL}$ concentrations. The discs loaded with extract were placed onto an organism swabbed medium in the petri plates which were incubated for $24 \mathrm{~h}$ at $37^{\circ} \mathrm{C}$. The antibacterial activity was expressed by measuring the diameter zone of inhibition formed around the disc [17, 18]. Tetracycline $(25 \mu \mathrm{g})$ was used as a positive control (standard).

\section{Minimum inhibitory concentration}

The antimicrobial activity of the root extract was determined by resazurin microtiter assay method [19]. The inoculum, equivalent to a 0.5 McFarland turbidity standard, was prepared from each bacterial isolate in $\mathrm{MH}$ broth. Sterile PBS $(50 \mu \mathrm{L})$ was dispensed in each well of a sterile 96-well flat bottom plate. The root extract of various concentrations from $1000 \mu \mathrm{g} / \mathrm{mL}$ to $0.48 \mu \mathrm{g} / \mathrm{mL}$ was added by twofold serial dilutions. Tetracycline was used as the positive control in separate wells. Separate wells with negative control (culture with no plant extract) were also performed. To each well, $10 \mu \mathrm{L}$ of resazurin indicator solution was added, followed by the addition of $30 \mu \mathrm{L}$ of threefold strength $\mathrm{MH}$ broth. The plates were incubated at $37^{\circ} \mathrm{C}$ in an incubator for $12-$ $24 \mathrm{~h}$ for further growth if any was detected. The change in colour of the dye added to the wells from blue to pink indicated the growth of bacteria. The MIC was defined as the lowest concentration of each test compound or drug that prevented any colour change observed visually, i.e., the concentration that inhibited the microbial growth.

\section{Cytotoxicity}

\section{MTT assay}

Cell viability was measured with the conventional MTT reduction assay, as described previously with slight modification. Briefly, human dermal fibroblast (HDF) cells were seeded at a density of $5 \times 10^{3}$ cells/well in 96well plates for $24 \mathrm{~h}$, in $200 \mu \mathrm{L}$ of RPMI with $10 \%$ FBS. Then, the culture supernatant was removed and RPMI containing root extract of $S$. heyneanus of various concentrations of $10-500 \mu \mathrm{g} / \mathrm{mL}$ was added and incubated for $48 \mathrm{~h}$. After treatment, the cells were incubated with MTT $(10 \mu \mathrm{L}, 5 \mathrm{mg} / \mathrm{mL})$ at $37^{\circ} \mathrm{C}$ for $4 \mathrm{~h}$ and then with DMSO at room temperature for $1 \mathrm{~h}$. The plates were read at $595 \mathrm{~nm}$ on a scanning multi-well spectrophotometer [20]. Data are represented as the mean values for three independent experiments:

$$
\text { Cell viability }(\%)=\left(\frac{\text { Mean OD }}{\text { Control OD }}\right) \times 100
$$

\section{Statistical analysis}

Statistical analysis was performed by one-way analysis of variance (ANOVA) using Graph Pad Prism 8.0.1. Differences in the mean between observations were considered significant at level $p<0.05$. All values acquired are cumulative of three replicates, and it was represented as a mean \pm standard deviation.

\section{Results}

Qualitative phytochemical analysis

The phytochemical analysis of the root extract of S. heyneanus showed the presence of compounds such as alkaloids, steroids, terpenoids, phenols, flavonoids, tannins, saponins, glycosides, and carbohydrates (Table 1).

\section{Total phenols and flavonoids}

Many phenolic acids and flavonoids possess antimicrobial, antiviral, and cytotoxic activity and have been reported to stimulate the secretion of bile acids and to prevent enzymatic reactions [21]. The total phenolic content of methanol root extract was $126.53 \pm 2.29 \mu \mathrm{g} /$ $\mathrm{mg}$ of GAE of extract, and the flavonoid content of methanol root extract was $32.79 \pm 0.62 \mu \mathrm{g} / \mathrm{mg}$ of $\mathrm{QE}$ of extract (Table 2).

\section{$\mathrm{DPPH}^{\bullet}$ radical scavenging activity}

The DPPH radical is a stable free radical due to the delocalization of an odd electron over the molecule, thus preventing dimer formation. This radical is used in the DPPH radical scavenging assay to measure the ability of antioxidants to quench the DPPH free radical. The dark purple colour of DPPH will be changed to yellow when it is reduced to non-radical [22]. The reducing capacity increases by increasing the concentration of the extract, and the highest $\mathrm{DPPH}^{\bullet}$ radical scavenging activity was $88.23 \pm 1.32 \%$ at $120 \mu \mathrm{g} / \mathrm{mL}$ concentration (Supplementary Information, Table S1). The methanol root extract of $S$. heyneanus has a reliable radical scavenging ability, 
Table 1 Phytochemical analysis summary of root extract of Strobilanthes heyneanus

\begin{tabular}{|c|c|c|c|}
\hline Phytochemicals & Test & Inference & Results \\
\hline Alkaloids & $\begin{array}{l}\text { Hager's test: To the extract, a saturated aqueous solution of picric acid was added and shaken } \\
\text { well. }\end{array}$ & $\begin{array}{l}\text { Formation of yellow } \\
\text { precipitate }\end{array}$ & + \\
\hline Steroids & $\begin{array}{l}\text { Liebermann-Burchard's test: The extract was mixed with } 1 \mathrm{~mL} \text { of acetic anhydride and shaken } \\
\text { well. To this, few drops of conc. } \mathrm{H}_{2} \mathrm{SO}_{4} \text { were added along the sides of the test tube. }\end{array}$ & $\begin{array}{l}\text { Appearance of dark } \\
\text { violet colour }\end{array}$ & + \\
\hline Terpenoids & $\begin{array}{l}\text { Salkowski test: To the extract, chloroform was added and mixed well. Then, a few drops of conc. } \\
\mathrm{H}_{2} \mathrm{SO}_{4} \text { were added along the sides of the test tube. }\end{array}$ & $\begin{array}{l}\text { Appearance of red } \\
\text { ring }\end{array}$ & + \\
\hline Phenols & $\mathrm{FeCl}_{3}$ test: To the extract, a few drops of $5 \% \mathrm{FeCl}_{3}$ solution was added and shaken well. & $\begin{array}{l}\text { Appearance of violet } \\
\text { colour }\end{array}$ & + \\
\hline Flavonoids & $\begin{array}{l}\text { Alkaline reagent test: To the extract, a few drops of } 2 \% \mathrm{NaOH} \text { solution was added and shaken } \\
\text { well. }\end{array}$ & $\begin{array}{l}\text { Appearance of } \\
\text { yellow colour }\end{array}$ & + \\
\hline Tannins & $\begin{array}{l}\text { Lead acetate test: To the extract, a few drops of } 5 \% \mathrm{~Pb}\left(\mathrm{CH}_{3} \mathrm{COO}\right)_{2} \text { solution was added and } \\
\text { shaken well. }\end{array}$ & $\begin{array}{l}\text { Appearance of white } \\
\text { colour }\end{array}$ & + \\
\hline Saponins & Foam test: To the extract, $3 \mathrm{~mL}$ of distilled water was added and shaken vigorously. & Appearance of foam & + \\
\hline Glycosides & $\begin{array}{l}\text { Legal's test: To the extract, few drops of pyridine and few drops of alkaline sodium nitroprusside } \\
\text { solution was added and shaken well. }\end{array}$ & $\begin{array}{l}\text { Appearance of blood } \\
\text { red colour }\end{array}$ & + \\
\hline Carbohydrates & $\begin{array}{l}\text { Molisch test: To the extract, two drops of alcoholic a-naphthol solution was added and shaken } \\
\text { well. To this, a few drops of conc. } \mathrm{H}_{2} \mathrm{SO}_{4} \text { was added. }\end{array}$ & $\begin{array}{l}\text { Appearance of violet } \\
\text { ring }\end{array}$ & + \\
\hline
\end{tabular}

$(+)=$ present; $(-)=$ absent

and the $\mathrm{IC}_{50}$ was $38.52 \mu \mathrm{g} / \mathrm{mL}$ concentration (Fig. 2). The $\mathrm{IC}_{50}$ was compared with the standard quercetin $\left(\mathrm{IC}_{50}=3.11 \mu \mathrm{g} / \mathrm{mL}\right.$ concentration $)$.

\section{$\mathrm{OH}^{\bullet}$ radical scavenging activity}

Hydroxyl radicals are the major active oxygen species causing lipid peroxidation and massive damage in proteins due to the reduction of disulphide bonds, specifically fibrinogen. In living organisms, hydroxyl radical is continuously formed in a reduction process of oxygen into the water, and it causes many diseases such as cancer, atherosclerosis, and neurological disorders and can be prevented by the antioxidant substances [23]. The highest $\mathrm{OH}^{\bullet}$ radical scavenging activity of root extract was $51.28 \pm 1.06 \%$ at $120 \mu \mathrm{g} / \mathrm{mL}$ concentration (Supplementary Information, Table S1), and the $\mathrm{IC}_{50}$ was $117 \mu \mathrm{g} / \mathrm{mL}$ concentration (Fig. 2). The $\mathrm{IC}_{50}$ was compared with the standard quercetin $\left(\mathrm{IC}_{50}=4.21 \mu \mathrm{g} / \mathrm{mL}\right.$ concentration).

\section{$\mathrm{ABTS}^{\bullet+}$ radical cation scavenging activity}

The antioxidant activity of the root extract was calculated by the decolorization of blue-green colour $\mathrm{ABTS}^{\bullet+}$ radical cation, which was measured

Table 2 Estimation of phenols and flavonoids from root extract of S. heyneanus

\begin{tabular}{ll}
\hline Phytochemicals & Amount $(\boldsymbol{\mu g} / \mathbf{m g})$ \\
\hline Phenols & $126.53 \pm 2.29 \mathrm{GAE}$ \\
Flavonoids & $32.79 \pm 0.62 \mathrm{QE}$ \\
\hline
\end{tabular}

GAE Gallic acid equivalent, QE Quercetin equivalent spectrophotometrically at $734 \mathrm{~nm}$. The root extract was added to the preformed $\mathrm{ABTS}^{\bullet+}$ radical cation and can be reduced to ABTS in a dose-dependent manner [24]. The root extract showed the highest $\mathrm{ABTS}^{\bullet+}$ radical cation scavenging activity of $91.28 \pm 1.12 \%$ at $60 \mu \mathrm{g} / \mathrm{mL}$ concentration, and the $\mathrm{IC}_{50}$ was $33.92 \mu \mathrm{g} / \mathrm{mL}$ concentration (Fig. 3; Supplementary Information Table S2). The $\mathrm{IC}_{50}$ was compared with the standard quercetin $\left(\mathrm{IC}_{50}=\right.$ $4.21 \mu \mathrm{g} / \mathrm{mL}$ concentration).

\section{Phosphomolybdenum reduction activity}

The reducing power of the root extract possesses various mechanisms such as the prevention of chain initiation, breakdown of peroxides, and inhibition of oxidation [25]. The highest phosphomolybdenum reduction of root extract was $87.43 \pm 0.90 \%$ at $120 \mu \mathrm{g} / \mathrm{mL}$ concentration, and the $\mathrm{RC}_{50}$ was $24.74 \mu \mathrm{g} / \mathrm{mL}$ concentration (Fig. 4; Table S3). The $\mathrm{RC}_{50}$ was compared with the standard quercetin $\left(\mathrm{RC}_{50}=6.34 \mu \mathrm{g} / \mathrm{mL}\right.$ concentration $)$.

\section{Ferric $\left(\mathrm{Fe}^{3+}\right)$ reducing power assay}

The root extract showed strong antioxidant activity due to the presence of phenolic compounds such as phenolic acids and flavonoids, which can donate electrons readily to the oxidising compounds [26]. The highest $\mathrm{Fe}^{3+}$ reduction was $89.38 \pm 0.98 \%$ at $120 \mu \mathrm{g} / \mathrm{mL}$ concentration, and the $\mathrm{RC}_{50}$ was $31.06 \mu \mathrm{g} / \mathrm{mL}$ concentration (Fig. 4; Supplementary Information Table S3). The $\mathrm{RC}_{50}$ was compared with the standard quercetin $\left(\mathrm{RC}_{50}=7.72 \mu \mathrm{g} /\right.$ mL concentration). 
DPPH` Radical

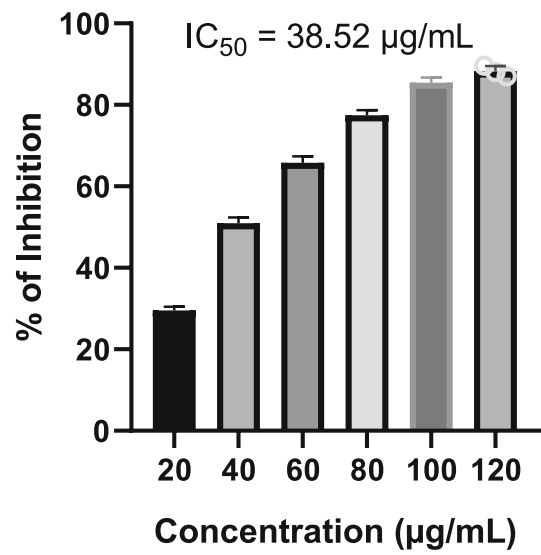

$\mathrm{OH}^{*}$ Radical

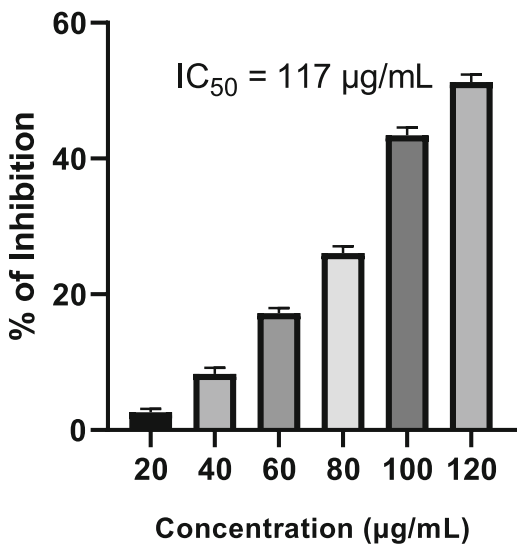

Fig. $2 \mathrm{DPPH}^{\bullet}$ radical and $\mathrm{OH}^{\bullet}$ radical scavenging activities of the root extract of $\mathrm{S}$. heyneanus. The results represent mean of triplicates along with standard deviation. Statistical significance-for $\mathrm{DPPH}^{\bullet}, t=-62.892$ and $p$ value $=3.829 \mathrm{e}-07$; for $\mathrm{OH}^{\bullet}, t=-71.485$ and $p$ value $=2.295 \mathrm{e}-07$

\section{Antibacterial activity}

Evaluation of the antibacterial activity of methanol root extract of $S$. heyneanus was determined by the disc diffusion method against the Gram-positive bacteria such as Bacillus subtilis and Staphylococcus aureus as well as the Gram-negative bacteria such as Salmonella typhi and Klebsiella pneumonia. The effectiveness of the root extract on bacterial strains was determined by calculating

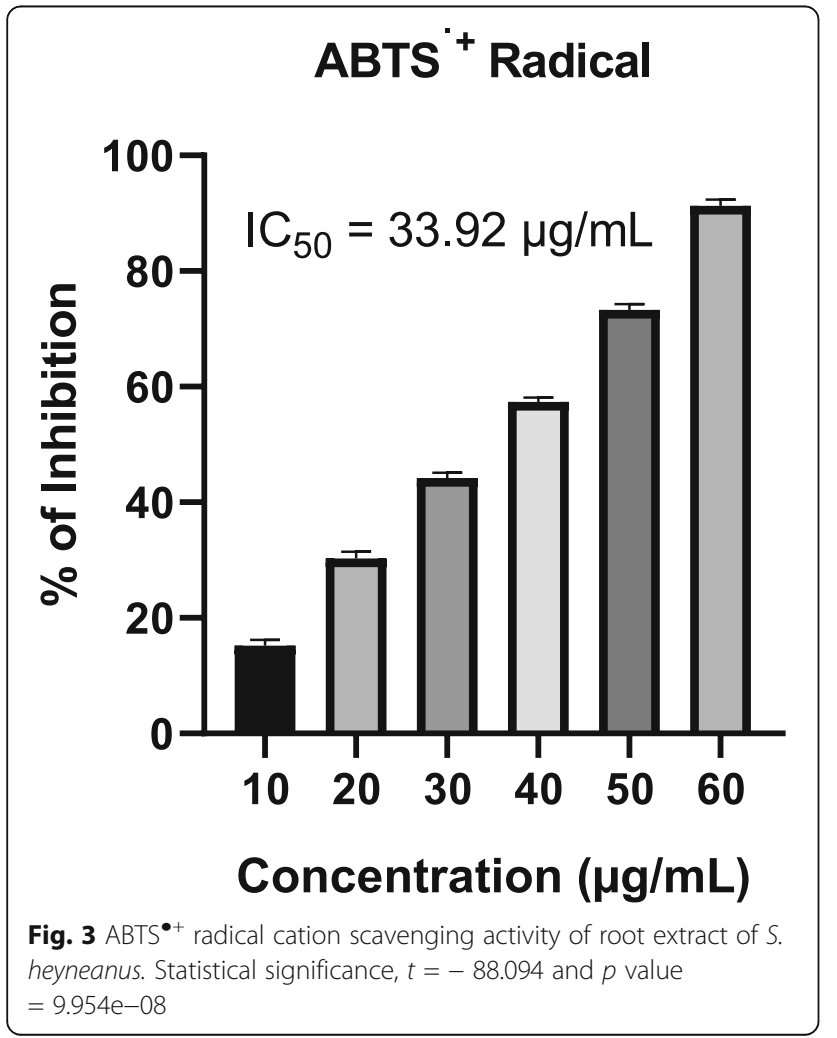

the zone of inhibition (Fig. 5). The root extract showed the highest zone of inhibition of $24 \mathrm{~mm}$ against Salmonella typhi at $500 \mu \mathrm{g} / \mathrm{mL}$ concentration (Table 3).

\section{Determination of MIC}

Staphylococcus aureus and Salmonella typhi showed no change in colour of resazurin indicator at a concentration of $62.25 \mu \mathrm{g} / \mathrm{mL}$ (column 5), which was taken as the MIC (Table 4). Similarly, Bacillus subtilis and Klebsiella pneumoniae showed no change in colour of resazurin indicator at a concentration of $31.25 \mu \mathrm{g} / \mathrm{mL}$ (column 6), which was taken as the MIC for root extract of $S$. heyneanus. The complete colour change was observed for negative control, indicating the growth of the organism in all wells (Fig. 6) [27]. The presence of blue colour for the positive control in all wells indicates complete inhibition of growth of the organism (Tetracycline).

\section{MTT assay}

MTT assay revealed that the root extract of $S$. heyneanus had no cytotoxic effect on HDF cells at the concentrations of 10 and $25 \mu \mathrm{g} / \mathrm{mL}$ (Fig. 7). But the root extract showed only mild toxicity resulting in cell viability of $97.76 \%$ at $50 \mu \mathrm{g} / \mathrm{mL}$ and $91.44 \%$ cells at $500 \mu \mathrm{g} / \mathrm{mL}$ (Supplementary Information Table S4). The root extract was tested for its cytotoxicity, considering that early screening of plant extract for toxicity might help in the evaluation of its biological and therapeutic value [28] (Fig. 8).

\section{Discussion}

Phytochemicals are naturally present in the plants, playing an essential role to defend themselves against various pathogenic microbes by showing antimicrobial activity. The secretion of these secondary metabolites is varying 

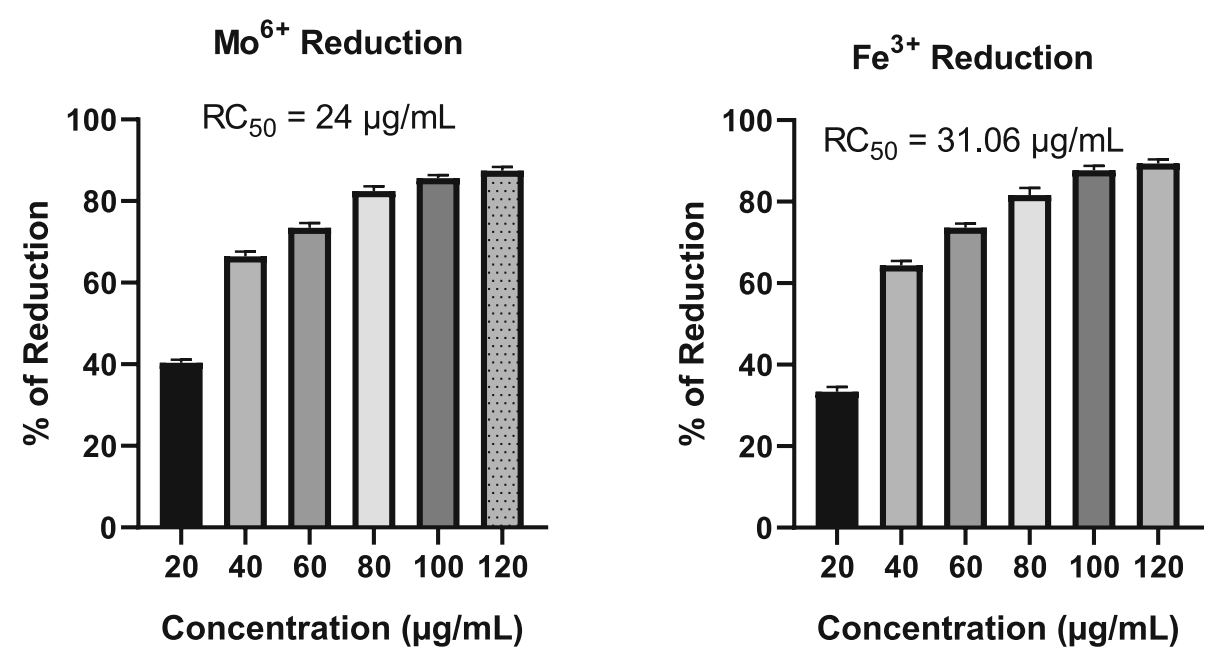

Fig. 4 Phosphomolybdenum reduction and $\mathrm{Fe}^{3+}$ reducing power activity of the root extract of $S$. heyneanus. Statistical significance-for phosphomolybdenum, $t=-70.397$ and $p$ value $=2.44 \mathrm{e}-07$; for $\mathrm{Fe}^{3+}, t=-64.639$ and $p$ value $=3.431 \mathrm{e}-07$

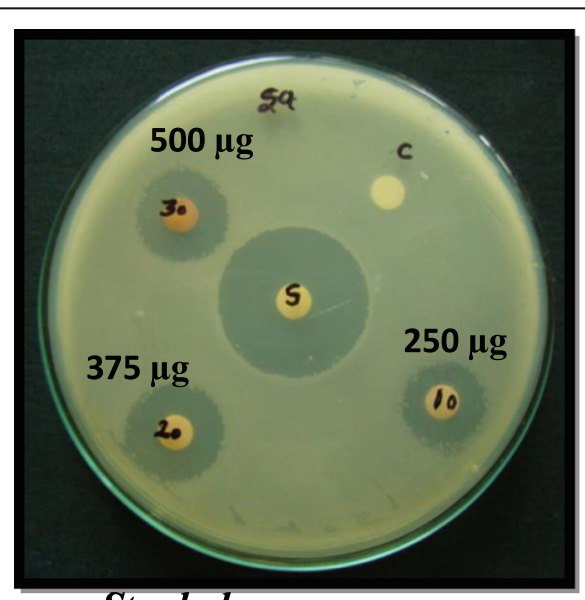

Staphylococcus aureus

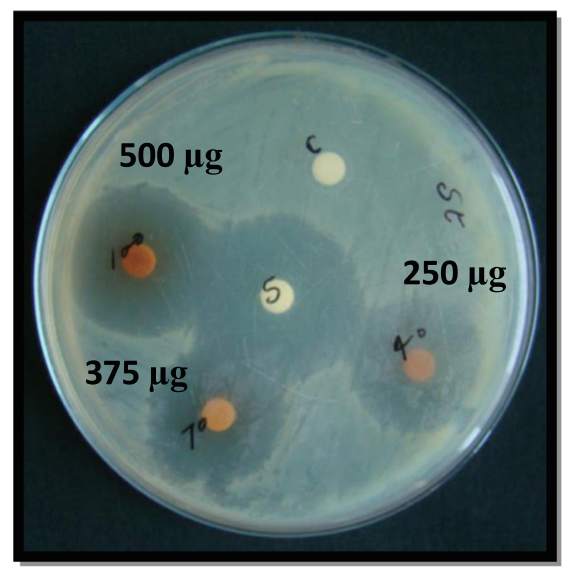

Salmonella typhi

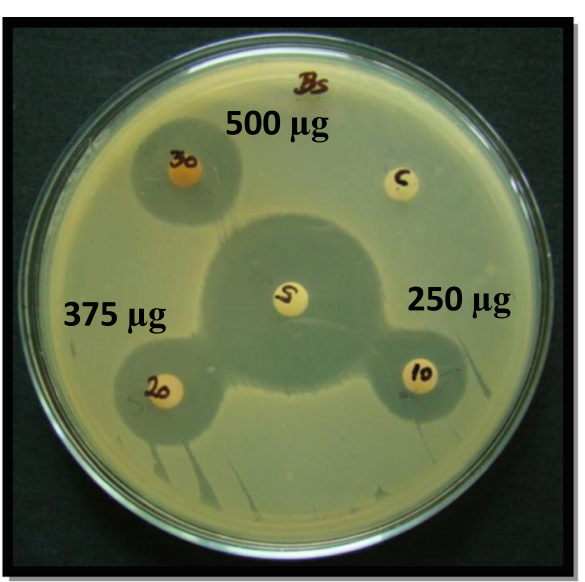

Bacillus subtilis

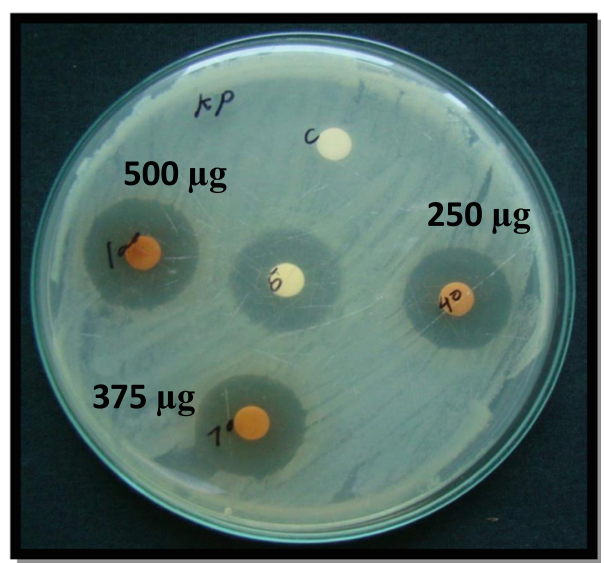

Klebsiella pneumoniae

Fig. 5 Antibacterial activity of root extract of S. heyneanus against four different bacterial species by disc diffusion tests. S, standard; C, negative control 
Table 3 Antibacterial activity of root extract of S. heyneanus against selected bacterial strains. NA, no activity

\begin{tabular}{|c|c|c|c|c|c|}
\hline \multirow[t]{2}{*}{ Organism } & \multicolumn{5}{|c|}{ Zone of inhibition (mm) } \\
\hline & $250 \mu \mathrm{g} / \mathrm{mL}$ & $375 \mu \mathrm{g} / \mathrm{mL}$ & $500 \mu \mathrm{g} / \mathrm{mL}$ & Standard (Tetracycline) & Negative control \\
\hline Staphylococcus aureus & 12 & 15 & 18 & 25 & NA \\
\hline Bacillus subtilis & 14 & 16 & 20 & 30 & NA \\
\hline Salmonella typhi & 17 & 19 & 24 & 26 & NA \\
\hline Klebsiella pneumoniae & 15 & 17 & 22 & 18 & NA \\
\hline
\end{tabular}

from plant to plant; while some plants produce more, others produce them only in minimal quantities. Some phytochemicals can be harmful and some can be quite helpful for the plants' survival. Phytochemicals in fruits, vegetables, and leaves may reduce the risk of diseases due to the presence of polyphenols, and terpenoids act as antioxidants and antimicrobial and anti-inflammatory agents.

The phytochemical analysis of the root extract showed the presence of terpenoids, phenolic compounds, flavonoids, and tannins [29, 30] which are responsible for antioxidant and antibacterial activity. Antioxidants are substances that may protect cells from ROS (reactive oxygen species) and free radicals which cause damage to cells. The phenolic acids and flavonoids, as effective antioxidants, play an important role in the control of different oxidative human diseases such as cancer inflammation, tissue damage, and DNA injury [31-33]. Antioxidant substances from natural products are good free radical scavengers leading to reduced risk of cancer development and protecting cells against the harmful effects of ROS on macromolecules, such as proteins, lipids, and DNA [34, 35]. Flavonoids and phenolic compounds as potential antioxidants may assist in health promotion by preventing oxidative damage responsible for many diseases [36]. Phenolic compounds increase the antioxidant enzyme activity and indirectly affecting the concentration of harmful oxygen radicals in the living cells and showed anti-inflammatory and anticancer activity [37]. Flavonoids eliminate pathological changes on capillaries and are used for the treatment of hypertension, diabetes, and atherosclerosis.

The radical scavenging ability of the root extract of $S$. heyneanus was carried out by $\mathrm{DPPH}^{\bullet}$ (1,1-diphenyl-2picrylhydrazyl) radical scavenging assay method. In this

Table 4 Minimal inhibitory concentration of root extract of $S$. heyneanus

\begin{tabular}{lll}
\hline S. no & Organism & MIC $(\boldsymbol{\mu g} / \mathbf{m L})$ \\
\hline 1 & Staphylococcus aureus & 62.25 \\
2 & Bacillus subtilis & 31.25 \\
3 & Salmonella typhi & 62.25 \\
4 & Klebsiella pneumoniae & 31.25 \\
\hline
\end{tabular}

method, the purple coloured DPPH (1,1-diphenyl-2picrylhydrazyl) radical solution turned to yellow coloured 1,1-diphenyl-2-picrylhydrazine, after the reduction of DPPH radical by the root extract due to the transfer of $\mathrm{H}$-atom from the extract [38]. The hydroxyl radical is a highly reactive free radical formed in the biological systems and has been capable of damaging proteins in living cells. The hydroxyl radicals can have the capacity to join nucleotides in DNA and can cause strand breakage, which leads to mutagenesis cytotoxicity and carcinogenesis [39]. The Fenton reaction generates hydroxyl radicals that degrade DNA deoxyribose and $\mathrm{Fe}^{2+}$ ions as an important catalytic component. Oxygen radicals may attack DNA either at the sugar or the base, giving rise to a large number of radical products. $\mathrm{H}_{2} \mathrm{O}_{2}$ is a non-free radical, and it can inactivate enzymes by the oxidation of thiol groups. It can cross the cell membrane quickly and slowly oxidise the various cell compounds and generate dangerous $\mathrm{OH}^{\bullet}$ radicals by the catalytic reaction using the metal ions $\mathrm{Fe}^{2+}$ and $\mathrm{Cu}^{2+}$, and this may be the triggering point of all its toxic effects.

$\mathrm{ABTS}^{\bullet+}$ radical cation is produced by the reaction between ABTS and potassium persulfate, which is a stable blue-green chromophore, with an absorption at $734 \mathrm{~nm}$. The antioxidants present in the root extract reacts with $\mathrm{ABTS}^{\bullet+}$ radical cation and reduces it to ABTS depending on the concentration and reactivity of the antioxidant. Antioxidants reduce the blue-green colour to colourless of the solution which is proportional to the antioxidants present in the root extract [40].

The reducing capacity of $S$. heyneanus root extract was determined by the phosphomolybdenum reduction assay method. The root extract reduces Mo (VI) to Mo (V) during the reaction and the blue or green phosphate/Mo (V) complex developed at acidic $\mathrm{pH}$, which has absorption at $695 \mathrm{~nm}$. The reducing power of $\mathrm{Fe}^{3+}$ to $\mathrm{Fe}^{2+}$ by the root extract of $S$. heyneanus was measured by the potassium ferricyanide reduction assay method, and the reduction capacity was found to be concentration-dependent. $\mathrm{Fe}^{3+}$ reducing power activity showed the electron-donating ability of an antioxidant and subsequent formation of the Ferroferric complex [41]. 


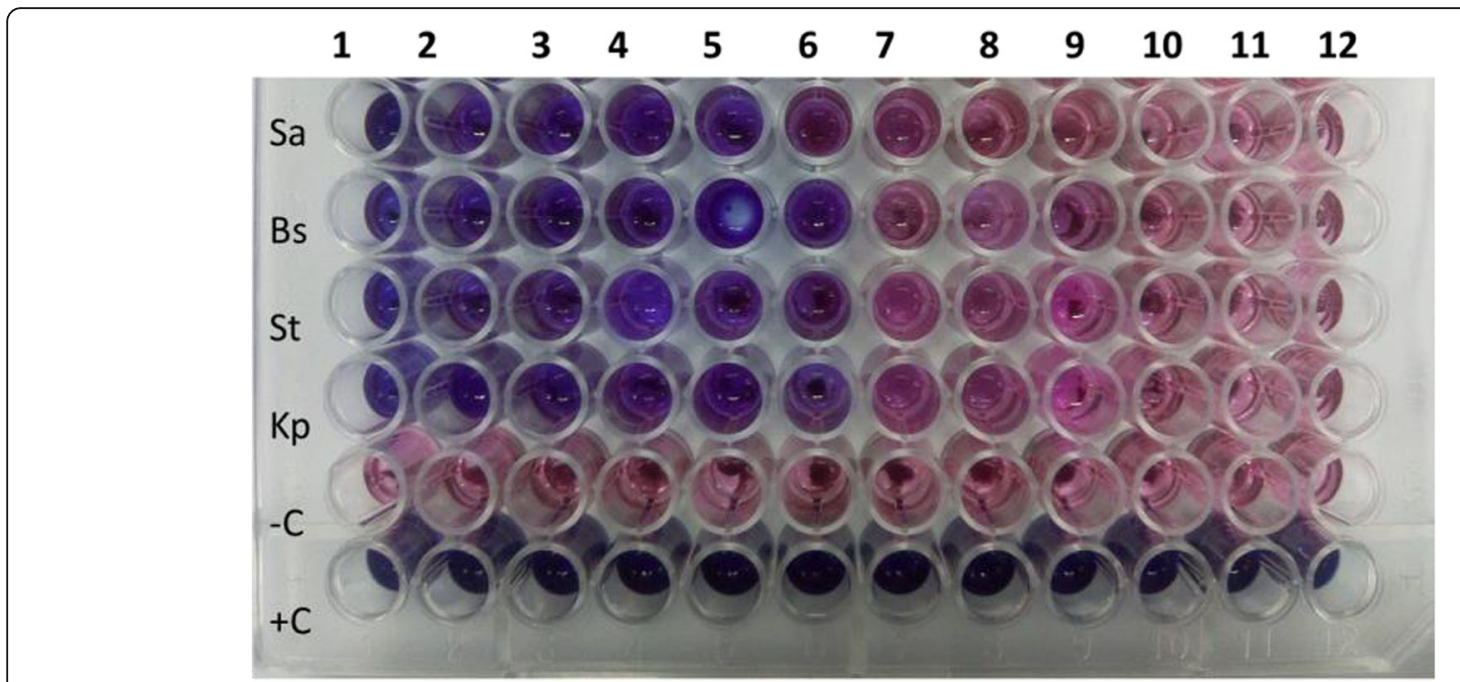

Fig. 6 MIC of root extract of S. heyneanus. Sa, Staphylococcus aureus; Bs, Bacillus subtilis; St, Salmonella typhi; Kp, Klebsiella pneumonia; -C, negative control; + C, positive control

The mechanism of action of the plant extracts revealed that plant polyphenols and terpenoids play important roles against bacteria, fungi, and viruses. Antibacterial activity in $S$. heyneanus has not been much reported yet, and the inhibition was reported mainly due to the presence of polyphenols [42]. The mechanism of bacterial inhibition by polyphenols is complex and they can act by chelating iron, which is important for the survival of many bacteria [43]. Antibacterial compounds in the root

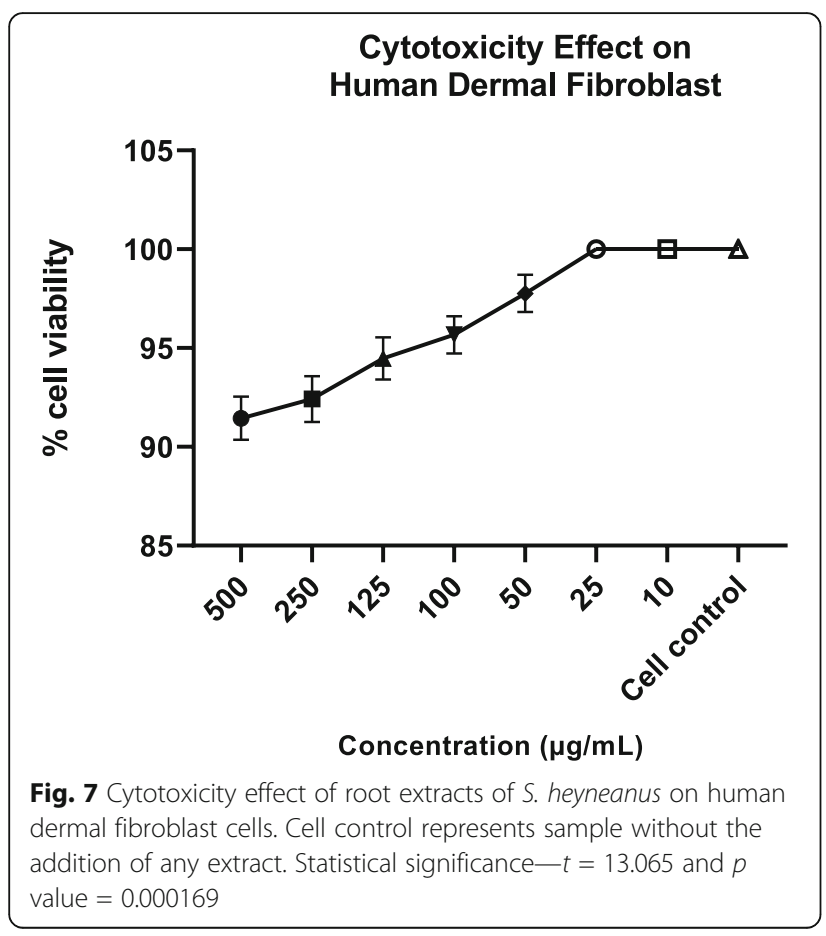

extract of S. heyneanus work together and producing an effect on microbial membranes, adhesins, enzymes, and cell envelope transport proteins. Polyphenols interact with proteins and/or phospholipids of the pathogens and increasing membrane permeability, modifying ion transport processes, and damaging cell membranes [44, 45]. Plant extracts would help cells to survive under conditions that progressively break intracellular machinery (free radical scavenging activities). On the other hand, the most efficient modern drugs kill cells, without discriminating between normal and cancer cells (free radicals attack). A single healthy cell mutation can provoke its transformation into a malignant phenotype. The MTT assay of the root extract of S. heyneanus on dermal fibroblasts cells showed the highest cell viability even at $500 \mu \mathrm{g} / \mathrm{mL}$ concentration [46].

\section{Conclusion}

Several natural products are derived from plants and have been used traditionally to treat many diseases such as wound healing, injuries, and pain. Current synthetic medicine and combinatorial chemistry linked with the new technological tools such as proteomics, genomics, and metabolomics covered the broader use of natural products. Currently, most natural products are produced and industrialised as pharmacologically active agents with potential antioxidant, anti-angiogenic, antiinflammatory, anti-infective, and anti-carcinogenic properties. Natural products have been engaged as the lead compounds to obtain extremely active pharmacological semi-synthetic derivatives for healing use with increased efficiency. The knowledge and practice from ancient times will significantly move to produce potential drugs 


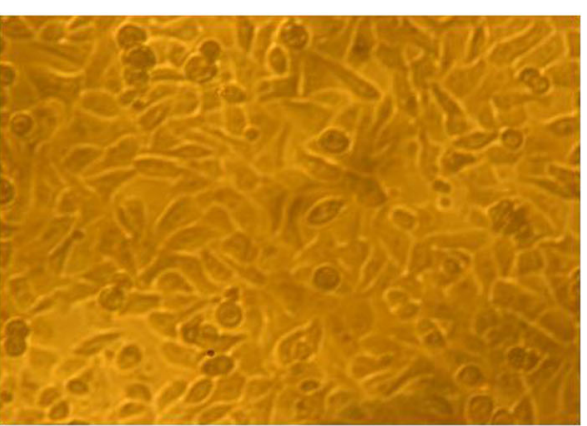

Normal dermal fibroblast

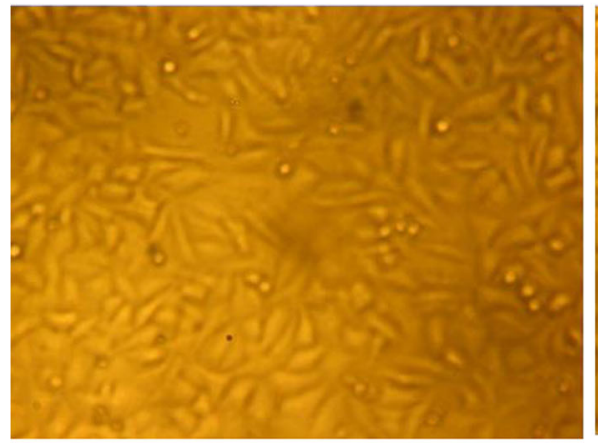

Toxicity $100 \mu \mathrm{g} / \mathrm{mL}$

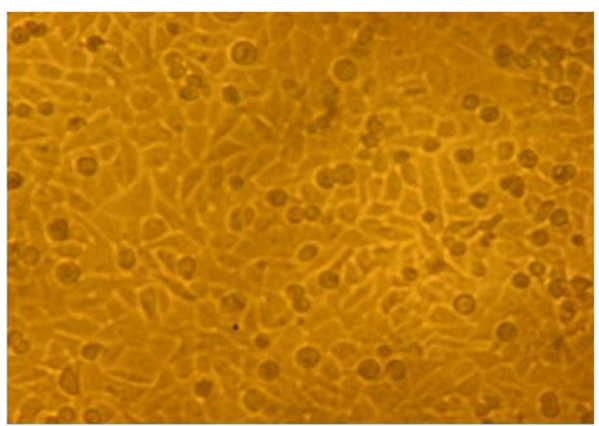

Toxicity $10 \mu \mathrm{g} / \mathrm{mL}$

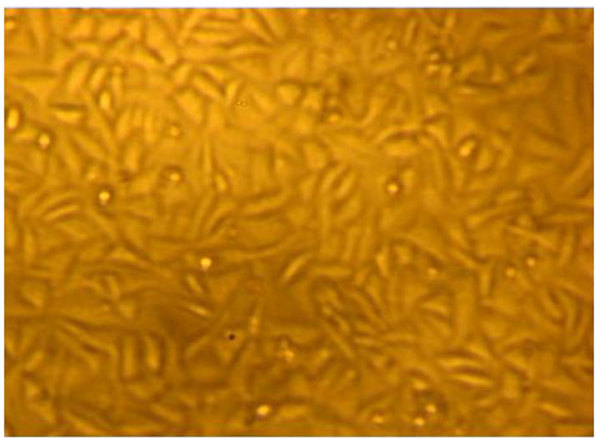

Toxicity $500 \mu \mathrm{g} / \mathrm{mL}$

Fig 8 Microscopic image of cytotoxicity tests of human dermal fibroblast with the root extracts of S. heyneanus

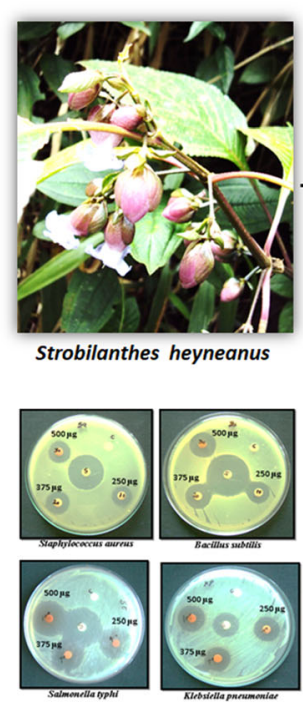

Antibacterial activity

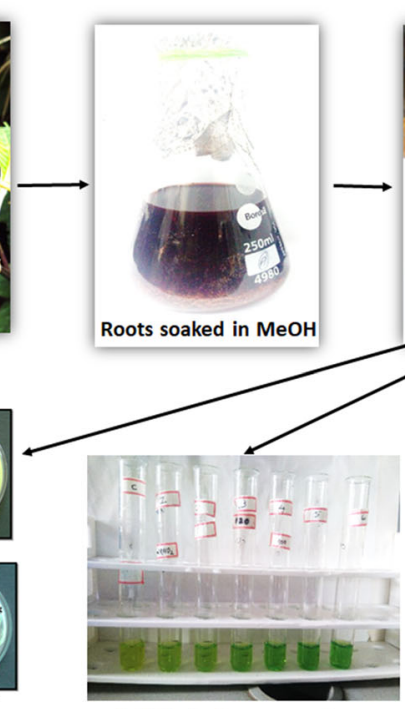

$\mathrm{Fe}^{3+}$ Reducing power Assay

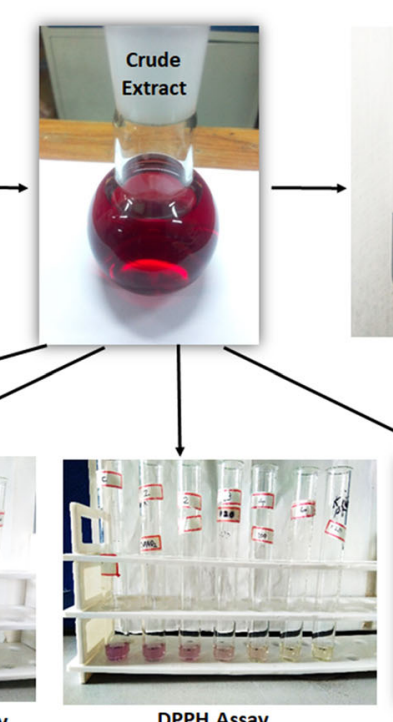

DPPH Assay

Fig. 9 ToC figure: pictorial representation of antioxidant and antibacterial activities of S. heyneanus 
for therapeutic strategy. There is considerable evidence that plant extracts, essential oils, and purified compounds have been used as a preventative agent or to treat various diseases. Hence, clinical trials of such natural products are essential for the safety and efficacy to offer therapeutic benefits before coming into the market. It should be helpful to use either alone or in combination with conventional therapies to reduce the overall burden of diseases worldwide. The present study showed that the root extract of $S$. heyneanus has good antioxidant properties and potential antibacterial agents. Further studies are necessary to isolate active compounds responsible for antibacterial activity in order to overcome the demand for natural antibiotics for human welfare (Fig. 9).

\section{Abbreviations}

ABTS $^{\bullet+}$ : (2,2'-and-bis (3-ethylbenzothiazoline-6-sulfonic acid); QE: Quercetin; DPPH: 1,1-Diphenyl-2-picrylhydrazyl; OH: Hydroxyl radical; FC: Folin-ciocalteu; GAE: Gallic acid equivalent; $\mathrm{Na}_{2} \mathrm{CO}_{3}$ : Sodium carbonate; PBS: Phosphate buffer saline; MTCC: The microbial type culture collection, and gene bank. MTT (3-[4,5-dimethylthiazol-2-yl]-2,5-diphenyl tetrazolium bromide) invitrogen, USA. Acridine orange was obtained from Sigma, USA.

\section{Supplementary Information}

The online version contains supplementary material available at https:/doi. org/10.1186/s43094-021-00242-2

Additional file 1: Supplementary Table S1 $\mathrm{DPPH}^{\bullet}$ radical and $\mathrm{OH}$ radical scavenging activities of the root extract of $S$. heyneanus.

Supplementary Table S2 ABTS $^{\bullet+}$ radical cation scavenging activity of root extract of S. heyneanus. Supplementary Table S3

Phosphomolybdenum reduction and $\mathrm{Fe}^{3+}$ reducing power activity of root extract of S. heyneanus. Supplementary Table S4 Cytotoxicity effect of root extract of $S$. heyneanus on Human dermal fibroblast

\section{Acknowledgements}

The authors are thankful to Vinayaraj for helping the collection of the plant and Dr. S. Noorunnisa Begum for the identification as well as the deposition of the plant at C-RMR.

\section{Plant authentication}

The plant material was authenticated by Dr. S. Noorunnisa Begum. The herbarium specimen was deposited at the Centre for Repository of Medicinal Resources (C-RMR), FRLH herbarium (voucher number is FRLH 120018), School of Conservation of Natural Resources, Transdisciplinary University, Bangalore

\section{Authors' contributions}

VS evaluated and interpreted the experimental data of the antioxidant, phytochemical screening, and antimicrobial activity, contributed to the characterization and bioassay, and inscribed the major part of the manuscript. SS contributed to the writing of the manuscript. SC was accompanying the supervision of the experiment. RN contributed to the guiding and configuring of the manuscript. AP contributed to the arranging of the MTCC organisms. All authors read and accepted the final manuscript.

\section{Funding}

No funding was obtained.

\section{Declarations}

Ethics approval and consent to participate

Not applicable.

\section{Consent for publication}

Not applicable.

\section{Competing interests}

No competing interest to declare.

\section{Author details}

${ }^{1}$ Department of Plant Biology and Plant Biotechnology, D.G Vaishnav College, Arumbakkam, Chennai, Tamilnadu 600106, India. ${ }^{2}$ ARMATS Biotek Training and Research Institute, Guindy, Chennai, Tamilnadu 600032, India. ${ }^{3}$ Centre for Advanced Studies in Botany, University of Madras, Guindy Campus, Chennai, Tamilnadu 600025, India. ${ }^{4}$ Department of Biotechnology, PRIST University, Vallam, Thanjavur, Tamil Nadu 613403, India.

Received: 18 September 2020 Accepted: 5 April 2021

Published online: 21 April 2021

\section{References}

1. Nair KV, Yoganarasimhan SN, Gopakumar K, Shantha TR, Keshavamurthy KR (1985) Studies on some South Indian market samples of Ayurvedic drugs-IV. Anc Sci Life 4(4):211-216 PMID: 22557481: PMCID: PMC3331526

2. Bhat G K (2014) Flora of South Kanara. Akriti Prints Mangalore India 638.

3. Nair RB, Ravishankar B, Vijayan NP, Sasikala CK, Saraswathy VN (1988) Antiinflammatory effect of Strobilanthus heyneanus leaves. A Biochemical Study. J Res Ay Sid 9(1-2):46

4. Kumar A, llavarasan R, Jayachandran T, Deecaraman M, Aravindan P, Padmanabhan N, Krishan MRV (2008) Hypoglycemic and hypolipidemic effect of Strobilanthes heyneanus in alloxan induced diabetic rats. J Med Plants Res 9:246-249

5. Baba SA, Malik SA (2015) Determination of total phenolic and flavonoid content, antimicrobial and antioxidant activity of a root extract of Arisaema jacquemontii Blume. J Taibah Univ Sci 9(4): 449-454. https://doi.org/https:// doi.org/10.1016/j.jtusci.2014.11.001

6. Aspé E, Fernández K (2011) The effect of different extraction techniques on extraction yield, total phenolic, and anti-radical capacity of extracts from Pinus radiata Bark. Ind Crops Prod 34:838-844. https://doi.org/https://doi. org/10.1016/j.indcrop.2011.02.002, 1

7. Pant DR, Pant ND, Saru DB, Yadav UN, Khanal DP (2017) Phytochemical screening and study of antioxidant, antimicrobial, antidiabetic, antiinflammatory and analgesic activities of extracts from stem wood of Pterocarpus marsupium Roxburgh. J Intercultural Ethnopharmacol 6(2):170176. https://doi.org/10.5455/jice.20170403094055

8. Amari NO, Bouzouina M, Berkani A, Lotmani B (2014) Phytochemical screening and antioxidant capacity of the aerial parts of Thymelaea hirsuta L. Asian Pac J Trop Dis 4(2):104-109. https://doi.org/https://doi.org/10.1016/ S2222-1808(14)60324-8

9. Kaur C, Kapoor HC (2002) Antioxidant activity and total phenolic content of some Asian vegetables. Int J FoodSci Technol 37: 153-161. httpsdoi.org/ https://doi.org/10.1046/j.1365-2621.2002.00552.x, 2

10. Ordonez AAL, Gomez JD, Vattuone MA (2006) Antioxidant activities of Sechium edule (Jacq.) Swartz extracts. Food Chem 97(3):452-458. https://doi. org/https://doi.org/10.1016/j.foodchem.2005.05.024

11. Trinh PC, Thao LTT, Ha HTV, Nguyen T (2020) DPPH-scavenging and antimicrobial activities of asteraceae medicinal plants on uropathogenic bacteria. Evid Based Complement Altern Med https://doi.org/https://doi. org/10.1155/2020/7807026, 2020, 1, 9

12. Smirnoff N, Cumbes QJ (1989) Hydroxyl radical scavenging activity of compatible solutes. Phytochemistry 28:1057-1060. https://doi.org/https://doi. org/10.1016/0031-9422(89)80182-7, 4

13. Farahziela Abu, Che Norma Mat Taib, Mohamad Aris Mohd Moklas, Sobri Mohd Akhir (2017) Antioxidant properties of crude extract, partition extract, and fermented medium of Dendrobium sabin flower. Evid Based Complement Altern Med https://doi.org/https://doi.org/10.1155/2017/2 907219, 2017, 1, 9

14. Prieto P, Pineda M, Aguilar M (1999) Spectrophotometric quantitation of antioxidant capacity through the formation of a phosphomolybdenum 
complex: specific application to the determination of vitamin E. Anal Biochem 269(2):337-341. PMID: 10222007. https://doi.org/10.1006/abio.1 999.4019

15. Pulido R, Bravo L, Saura Calixto F (2000) Antioxidant activity of dietary polyphenols as determined by a modified ferric reducing antioxidant power assay. J Agric Food Chem 48(8):3396-3402. PMID: 10956123. https://doi. org/10.1021/jf9913458

16. Pollock HM, Barry AL, Gavan TL, Fuchs PC, Hansen S, Thornsberry CL, Frankel $H$, Forsythe, SB (1986) Selection of a reference lot of Mueller-Hinton agar. J Clin Microbiol 24(1):1-6. https://doi.org/https://doi.org/10.1128/JCM.24.1.16.1986

17. Murray PR, Zeitinger JR (1983) Evaluation of Mueller-Hinton agar for disk diffusion susceptibility tests. J Clin microbiol 18(5):1269-1271. https://doi. org/https://doi.org/10.1128/JCM.18.5.1269-1271.1983

18. Barry AL, Creitz L, Packer RR (1985) Feasibility study of disk diffusion susceptibility tests with Mueller-Hinton broth solidified with Gelrite, an agar substitute. J Clin Microbiol 21(3): 409-414. https://doi.org/https://doi.org/1 0.1128/JCM.21.3.409-414.1985

19. Sarker SD, Nahar L, Kumarasamy Y (2007). Microtitre plate-based antibacterial assay incorporating resazurin as an indicator of cell growth, and its application in the in vitro antibacterial screening of phytochemicals. Methods 42: 321-324. https://doi. org/https://doi.org/10.1016/j.ymeth.2007. 01.006 .

20. Latif MA, Ibrahim FW, Arshad SA, Hui CK, Jufri NF Hamid A (2019) Cytotoxicity, proliferation and migration rate assessments of human dermal fibroblast adult cells using Zingiber Zerumbet extract. Sains Malays 48:121127. http://dx.doi.org/https://doi.org/10.17576/jsm-2019-4801-14, 1

21. Pandey KB, Rizvi SI (2009) Plant polyphenols as dietary antioxidants in human health and disease. Oxid Med Cell Longev 2(5): 270-278. https://doi. org/https://doi.org/10.4161/oxim.2.5.9498

22. Ak T, Gülçin, I (2008) Antioxidant and radical scavenging properties of curcumin. Chem Biol Interact 174(1):27-37. https://doi.org/https://doi.org/1 0.1016/j.cbi.2008.05.003

23. Lipinski B (2011) Hydroxyl radical and its scavengers in health and disease. Oxidative medicine and cellular longevity. https://doi.org/https://doi.org/1 0.1155/2011/809696, 2011, 1, 9

24. Ilyasov Igor R, Beloborodov, Vladimir L, Selivanova, Irina A, Terekhov Roman P (2020) "ABTS/PP decolorization assay of antioxidant capacity reaction pathways". Int J Mol Sci 21(3):1131. https://doi.org/https://doi.org/10.3390/ ijms21031131

25. Alam N, Hossain M, Mottalib M A, Sulaiman SA, Gan, SH, Khalil MI (2012) Methanolic extracts of Withania somnifera leaves, fruits and roots possess antioxidant properties and antibacterial activities. BMC Complement Altern Med, 12-175. https://doi.org/https://doi.org/10.1186/1472-6882-12-175, 12, 1

26. Shahidi F, Ambigaipalan P (2015) Phenolics and polyphenolics in foods, beverages and spices. Antioxidant activity and health effects. A review. J Funct Foods 18:820-897

27. Elshikh M, Ahmed S, Funston S, Dunlop P, McGaw M, Marchant R, Banat IM (2016) Resazurin-based 96-well plate micro dilution method for the determination of minimum inhibitory concentration of bio surfactants. Biotechnol Lett 38(6):1015-1019. https://doi.org/10.1007/s10529-016-2079-2

28. Makhafola TJ, McGaw LJ, Eloff JN (2014) In vitro cytotoxicity and genotoxicity of five Ochna species (Ochnaceae) with excellent antibacterial activity. S Afr J Botany 91:9-13. https://doi.org/10.1016/j.sajb.2013.11.010

29. Andre CM, Larondelle Y, Evers D (2010) Dietary antioxidants and oxidative stress from a human and plant perspective: a review. Curr Nutr Food Sci 6(1):2-12. https://doi.org/10.2174/157340110790909563

30. Zhang YJ, Gan, RY, Li S, Zhou Y, Li AN, Xu DP, Li HB (2015) Antioxidant phytochemicals for the prevention and treatment of chronic diseases. Molecules 20(12): 21138-21156. https://doi.org/https://doi.org/10.3390/ molecules201219753

31. Uttara B, Singh AV, Zamboni P, Mahajan RT (2009) Oxidative stress and neurodegenerative diseases. A review of upstream and downstream antioxidant therapeutic options. Curr Neuropharmacol 7(1):65-74. https:// doi.org/10.2174/157015909787602823

32. Kim D, Jeond S \& Lee C (2003) Antioxidant capacity of phenolic phytochemicals from various cultivars of plums. Food Chem 81:321-326. https://doi.org/https://doi.org/10.1016/S0308-8146(02)00423-5, 3

33. Halliwell B, Gutteridge JMC (1990) Role of free radicals and catalytic metal ions in human disease: an overview. Methods Enzymol 186:80-85. PMID: 2172697. https://doi.org/10.1016/0076-6879(90)86093-b
34. Lee SJ, Son KH, Chang HW (1993) Anti-inflammatory activity of naturally occurring flavone and flavonol glycosides. Arch Pharm Res 16: 25-28. https://doi.org/https://doi.org/10.1007/BF02978244, 1

35. Vessal M, Hemmati M \& Vasei M (2003) Antidiabetic effects of quercetin in streptozocin-induced diabetic rats. Comp Biochem Physiol C Toxicol Pharmacol, 135(3): 357-364. https://doi.org/https://doi.org/10.1016/\$1532-04 56(03)00140-6

36. Tungmunnithum, D, Thongboonyou A, Pholboon A, Yangsabai A (2018) Flavonoids and other phenolic compounds from medicinal plants for pharmaceutical and medical aspects: an overview. Medicines (Basel, Switzerland). 5(3): 93. https://doi.org/https://doi.org/10.3390/medicines503 0093

37. Lobo V, Patil, A, Phatak A, Chandra N (2010) Free radicals, antioxidants and functional foods: impact on human health. Pharmacognosy Rev 4(8):118126. https://doi.org/https://doi.org/10.4103/0973-7847.70902

38. Manian R, Anusuya N, Siddhuraju P, Manian S (2008) The antioxidant activity and free radical scavenging potential of two different solvent extracts of Camellia sinensis (L.) O. Kuntz, Ficus bengalensis L., and Ficus racemosa L. Food Chem 107(3):1000-1007. https://doi.org/10.1016/j.foodchem.2007.09. 008

39. Leong LP, Shui G (2002) An investigation of antioxidant capacity of fruits in Singapore markets. Food Chem. 7:69-75. https://doi.org/https://doi.org/10.1 016/S0308-8146(01)00251-5

40. Mahitha B, Archana P, Ebrahimzadeh MH, Srikanth K, Rajinikanth M, Ramaswamy N (2015) In vitro antioxidant and pharmacognostic studies of leaf extracts of Cajanus cajan (I.) Mill sp. Indian J Pharm Sci 77(2):170 PMCID: PMC4442465 PMID: 26009649

41. Pietta PG (2000) Flavonoids as antioxidants. J Nat Prod 63:1035-1042. PMID: 10924197. https://doi.org/10.1021/np9904509

42. Othman L, Sleiman A, \& Abdel-Massih RM (2019) Antimicrobial activity of polyphenols and alkaloids in middle eastern plants. Front Microbiol 10:911. https://doi.org/https://doi.org/10.3389/fmicb.2019.00911

43. Lu Y, Foo LY (2002) Polyphenolics of Salvia-a review. Phytochemistry 59(2): 117-140. https://doi.org/10.1016/S0031-9422(01)00415-0

44. Cho YS, Schiller NL, Kahng HY, Oh KH (2007) Cellular responses and proteomic analysis of Escherichia coli exposed to green tea polyphenols. Curr. Microbiol. 55:501-506. PMID: 17874165 DOI: 10.1007/s00284-007-90218,6

45. Yi S, Wang W, Bai F, Zhu J, Li J, Li X, Xu I, Sun T, He Y (2014) Antimicrobial effect and membrane-active mechanism of tea polyphenols against Serratia marcescens. World J Microbiol. Biotechnol. 30(2):451-460. https://doi.org/1 0.1007/s11274-013-1464-4

46. Bolla SR, Al-Subaie AM, Al-Jindan RY, Balakrishna JP, Ravi PK, Veeraraghavan VP, Surapaneni KM (2019) In vitro wound healing potency of methanolic leaf extract of Aristolochia saccata is possibly mediated by its stimulatory effect on collagen-1 expression. Heliyon 5(5):e01648. https://doi.org/10.101 6/j.heliyon.2019.e01648

\section{Publisher's Note}

Springer Nature remains neutral with regard to jurisdictional claims in published maps and institutional affiliations.

\section{Submit your manuscript to a SpringerOpen ${ }^{\circ}$ journal and benefit from:}

- Convenient online submission

- Rigorous peer review

- Open access: articles freely available online

High visibility within the field

- Retaining the copyright to your article

Submit your next manuscript at $>$ springeropen.com 